\title{
Pathological correlation between prostate biopsies and the radical prostatectomy, about 30 cases
}

\author{
Sow Aboubakry* (D, Tazi Mohammed Fadl, Ahsaini Moustapha, Mellas Soufiane, El Ammari Jalal Eddine, \\ El Fassi Mohammed Jamal and Farih My Hassan
}

\begin{abstract}
Background: Since the advent of the massive prostate-specific antigen (PSA) testing, prostate cancer has become a major public health problem. It is currently the most common cancer and the second leading cause of cancer death in men. The diagnosis is based on the histopathological study of prostate biopsies. The aim of our work was to study the correlation of the grade group (GG) using the ISUP 2016 classification between the prostate needle biopsies and radical prostatectomy specimen.
\end{abstract}

Methods: This was a retrospective study of 30 patients. We studied the correlation of the grade group (GG) according to the new classification ISUP (2016) between prostate biopsies and radical prostatectomy specimen.

Results: The average age of our patients was 65 years, the diagnosis was discovered on an individual screening in $15 \%$ of the cases, and $65 \%$ of our patients were diagnosed with LUTS due to an associated benign prostatic hyperplasia. The average PSA level in our study was $11 \mathrm{ng} / \mathrm{ml}$. In the biopsies group, the grade 1 and 2 groups were in the majority with $40 \%$ of the cases each of them. We noted that GG 3 (Gleason $4+3$ ) was represented in $16.66 \%$ of cases, while GG4 was only present in 3\% of cases. On the prostatectomy specimen group, GG1 was represented in 33.33\% of cases, GG2 in $40 \%$ of cases and GG3 in 20\% of cases. GG4 was represented in $6.66 \%$ of cases. Among GG1 patients, identical staging was noted in $75 \%$ of cases, and under-staging in $25 \%$ of cases. For GG2 patients, over-staging in $8.3 \%$ of cases, identical staging in $83.3 \%$ of cases and under-staging of $8.3 \%$. Among GG 3 patients, there was an $80 \%$ identical staging, while an under-staging was present in $20 \%$ of cases. The GG 4 is perfectly correlated. Combining all groups in our study, we noted an exact staging in $80 \%$ of the cases, an under-staging in $16.33 \%$ of the cases, and an over-staging in 3.33\% of the cases. The Kappa concordance index was 0.4 .

Conclusions: The correlation of the grade group between the prostate biopsies and the radical prostatectomy specimen was imperfect; the more the cancer increases in the grade group, the better was the correlation.

Keywords: Biopsy, Prostate, Radical prostatectomy specimen, Grade group, Correlation

\section{Background}

Since the advent of the massive prostate-specific antigen (PSA) testing, prostate cancer has become a major public health problem. The most common malignancy of the prostate is adenocarcinoma, accounting for more

\footnotetext{
*Correspondence: saboubakry10@gmail.com

Urology Department, Centre Hospitalier Universitaire Hassan II, Fes, Morocco
}

than $25 \%$ of all malignancies in male [1]. The diagnosis is based on the histopathological study of prostate biopsies. The Gleason score has been updated since 2016. Thus, the traditional classification is set to disappear, replaced by the ISUP grade group (GG). At the localized stage, radical prostatectomy remains the standard therapeutic in patients with an extended life expectancy. The objective of our work was to study the correlation of the grade group (GG) according to the new ISUP classification 
(2016) between the prostate biopsies and radical prostatectomy specimen across a series of 30 patients, as well as the main epidemiological characteristics, clinical and therapeutic of patients.

\section{Methods}

This is a retrospective study of 30 patients. We studied the correlation of the grade group (GG) according to the new ISUP classification (2016) between prostate biopsies and radical prostatectomy specimen across a series of 30 patients, as well as the main epidemiological, clinical and therapeutic characteristics of the patients. We used SSPS software in version 20. In this study, we included all patients who underwent radical prostatectomy in our department during 5 years.

The measurement of agreement was made by the Kappa concordance index proposed by Cohen in 1960.

\section{Results}

The diagnosis was discovered on an individual screening in $15 \%$ of cases, and $65 \%$ of our patients were diagnosed with LUTS due to an associated benign prostatic hyperplasia. The prostate volume varies between 20 and $70 \mathrm{~mL}$ with an average of $44 \mathrm{~mL}$.

The average of the PSA level in our study was $11 \mathrm{ng} /$ $\mathrm{mL} ; 70 \%$ of patients had a PSA level below $10 \mathrm{ng} / \mathrm{mL}$, $20 \%$ of patients between $10 \mathrm{ng} / \mathrm{mL}$ and $20 \mathrm{ng} / \mathrm{mL}$, and $10 \%$ above $20 \mathrm{ng} / \mathrm{mL}$. Adenocarcinoma was the only histological type in our study. All biopsies were performed with an $18 \mathrm{G}$ needle, by transrectal route with ultrasonography guidance. The average number of biopsies was 15 with extremes between 10 and 19. All patients were operated by retropubic prostatectomy. The most classic complications were represented by erectile dysfunction in $70 \%$ of cases and urinary incontinence in $20 \%$ of cases.

In the biopsies group, the grade 1 and 2 groups were in the majority with $40 \%$ of the cases each of them. We noted that GG 3 (Gleason 4+3) was represented in $16.66 \%$ of cases, while GG4 was only present in $3 \%$ of cases.

On the prostatectomy specimen group, GG1 was represented in $33.33 \%$ of cases, GG2 in $40 \%$ of cases and GG3 in 20\% of cases. GG4 was represented in $6.66 \%$ of cases (Table 1).

In this study, among the twelve GG1 patients, we noted nine patients who kept the same stage in GG1 which represents an identical staging in $75 \%$ of the cases, while two patients went to GG2 and one patient went to GG 3 which represents under-staging in $25 \%$ of cases.

Also, among the twelve GG2 patients, one patient (8.3\%) had an over-staging and returned to GG1, while ten patients (83.3\%) remained in GG2, and another one went to GG3 which represents an under-staging of $8.3 \%$.
Table 1 Grade groups

\begin{tabular}{lll}
\hline Grade group (GG) & Biopsies & Prostatectomy \\
\hline GG1 (Gleason 3+3) & $40 \%$ & $33.33 \%$ \\
& 12 cases/30 & 10 cases $/ 30$ \\
GG2 (Gleason 3+4) & $40 \%$ & $40 \%$ \\
& 12 cases/30 & 12 cases $/ 30$ \\
GG3 (Gleason 4+3) & $16.66 \%$ & $20 \%$ \\
& 5 cases/30 & 6 cases $/ 30$ \\
GG4 (Gleason 4+4, Gleason & $3 \%$ & $6.66 \%$ \\
$5+3$ Gleason 3+5) & 1 case/30 & 2 cases $/ 30$ \\
GG5 (Gleason 9 et 10) & - & - \\
\hline
\end{tabular}

Among the five GG 3 patients, the four remained in the same group which represents an identical staging of $80 \%$, while one patient switched to GG4 which represents an under-staging of $20 \%$. The only one patient in GG 4 remained in his group.

Combining all groups, we note an exact staging in $80 \%$ of the cases, an under-staging in $16.33 \%$ of the cases, and an over-staging in $3.33 \%$ of the cases. The Kappa concordance index was 0.4 .

\section{Discussion}

Gleason's histoprognostic grading of prostate biopsies is crucial in deciding the appropriate treatment of prostate cancer. The new classification in prognostic grade group aims to simplify and standardize behavior [1].

The average age in our study was 65 years, which is comparable to most studies. The Qarro study finds an average age of 62.8 years [2], the Boccon-Gibod series [3] (63.8 years), the Seong Cheol et al. [4] study (64.4 years), the Khiari and al study [5] (67 years) and that of Peko et al. [6] (69 years). The average PSA in our study was $11 \mathrm{ng} / \mathrm{mL}$, and it was lower than in the Carolina study (7.83 ng $\mathrm{mL}$ ) [7] and higher than in the Dehayni study $(15.17 \mathrm{ng} / \mathrm{ml})$ [8]. The recommended number of biopsies was 12 , and this number can increase in the presence of suspicious foci or can be lower in the case of small prostates. In our study, the average number of biopsies was 15, and it was 12.56 and 13.57 in the studies of Dehayni and Carolina, respectively.

It is well accepted that the histopathological correlation between prostate biopsies and the radical prostatectomy specimen is imperfect according to the data in the literature, which was also verified in our study. We note that the higher was the grade group, the best the correlation was (Table 2).

Dolatkhah [9] in a study of 100 patients reports that among 55 patients with GG1 on biopsies (Gleason $3+3$ ), an accuracy of $61.8 \%$ is observed. Among the 27 GG2 and GG3 biopsy patients, $48.1 \%$ had good correlation 
Table 2 Comparison of anatomopathological data on biopsies and prostatectomy

\begin{tabular}{|c|c|c|c|c|c|c|c|c|}
\hline \multirow[t]{2}{*}{ Grade group (GG) } & \multicolumn{4}{|l|}{ Biopsies } & \multicolumn{4}{|c|}{ Prostatectomy specimen } \\
\hline & Our Study n: 30 & Awang A. $n: 78$ & $\begin{array}{l}\text { Carolina } \\
\text { D'Elia } n: \\
300\end{array}$ & $\begin{array}{l}\text { Dolatkhah } \\
n: 100\end{array}$ & Our Study n: 30 & Awang A. $n: 78$ & $\begin{array}{l}\text { Carolina } \\
\text { D'Elia } n: \\
300\end{array}$ & $\begin{array}{l}\text { Dolatkhah } \\
n: 100\end{array}$ \\
\hline GG1 (Gleason 3+ 3) & $\begin{array}{l}40 \% \\
12 \text { cases }\end{array}$ & $\begin{array}{l}38 \% \\
29 \text { cases }\end{array}$ & $\begin{array}{l}64 \% \\
192 \text { cases }\end{array}$ & $78 \%$ & $\begin{array}{l}33.33 \% \\
10 \text { cases }\end{array}$ & $\begin{array}{l}12 \% \\
10 \text { cases }\end{array}$ & $\begin{array}{l}31 \% \\
93 \text { cases }\end{array}$ & $63 \%$ \\
\hline GG2 (Gleason 3+4) & $\begin{array}{l}40 \% \\
12 \text { cases }\end{array}$ & $\begin{array}{l}32 \% \\
25 \text { cases }\end{array}$ & $\begin{array}{l}15.6 \% \\
47 \text { cases }\end{array}$ & $13 \%$ & $\begin{array}{l}40 \% \\
12 \text { cases }\end{array}$ & $\begin{array}{l}46 \% \\
36 \text { cases }\end{array}$ & $\begin{array}{l}44.3 \% \\
133 \text { cases }\end{array}$ & $24 \%$ \\
\hline GG3 (Gleason 4+3) & $\begin{array}{l}16.66 \% \\
5 \text { cases }\end{array}$ & $\begin{array}{l}19 \% \\
15 \text { cases }\end{array}$ & $\begin{array}{l}5.7 \% \\
17 \text { cases }\end{array}$ & $5 \%$ & $\begin{array}{l}20 \% \\
6 \text { cases }\end{array}$ & $\begin{array}{l}29 \% \\
23 \text { cases }\end{array}$ & $\begin{array}{l}7.6 \% \\
23 \text { cases }\end{array}$ & $9 \%$ \\
\hline $\begin{array}{l}\text { GG4 (Gleason } 4+4 \\
\text { Gleason } 5+3 \text { Gleason } \\
3+5 \text { ) }\end{array}$ & $\begin{array}{l}3 \% \\
1 \text { case }\end{array}$ & $\begin{array}{l}7 \% \\
6 \text { cases }\end{array}$ & $\begin{array}{l}6.6 \% \\
20 \text { cases }\end{array}$ & $4 \%$ & $\begin{array}{l}6.66 \% \\
2 \text { cases }\end{array}$ & $\begin{array}{l}2 \% \\
1 \text { case }\end{array}$ & $\begin{array}{l}8.7 \% \\
26 \text { cases }\end{array}$ & $4 \%$ \\
\hline GG5 (Gleason $9+10)$ & - & $\begin{array}{l}3 \% \\
3 \text { cases }\end{array}$ & $\begin{array}{l}1 \% \\
3 \text { cases }\end{array}$ & - & - & $\begin{array}{l}10 \% \\
8 \text { cases }\end{array}$ & $\begin{array}{l}5.7 \% \\
17 \text { cases }\end{array}$ & - \\
\hline
\end{tabular}

with prostatectomy, while $48.1 \%$ were under-staged and $3.7 \%$ were over-staged. The patients with a high grade had a correct agreement in $66.7 \%$ of the cases. This study concludes that overall- and under-staging is noted in 34\% of cases and over-staging in $7 \%$ of cases, and the Kappa concordance index was 0.44 .

Carrolina D'Elia [7] in a series of 300 patients shows that on biopsies, patients with GG1, around $46.7 \%$ of cases had an over-staging in GG2 (Gleason $3+4$ ) and $5.3 \%$ in GG 3 (Gleason 4+3). For GG2 biopsy patients, $57.4 \%$ had identical staging. For GG3 patients, $23.5 \%$ of cases had GG2 under-staging and 35.3\% retained identical staging.

Awang [10], meanwhile, in his study of 78 patients shows that $48 \%$ of patients with GG1 (Gleason $3+3$ ) had under-staging during prostatectomy to GG2, $11 \%$ to GG 3 and $3 \%$ to GG4 $(3+5)$. For patients GG2 and 3, in $80 \%$ the patients had an identical group. The concordance index in this study is 0.32 .

These data were not far from our study where we noted among GG1 patients, identical staging in $75 \%$ of cases, and under-staging in $25 \%$ of cases. For GG2 patients, over-staging in $8.3 \%$ of cases, identical staging in $83.3 \%$ of cases and under-staging of $8.3 \%$. Among GG 3 patients, there was an $80 \%$ identical staging, while an under-staging was present in $20 \%$ of cases. The GG 4 was perfectly correlated.

\section{Conclusions}

Overall, the histopathological correlation of the grade group between the needle biopsies and the final radical prostatectomy specimen was good but not perfect. The higher was the grade group, the best the correlation was.
This must be considered in managing patients, and using prostate MRI before first biopsies can improve the accuracy of the correlation.

\section{Abbreviations \\ PSA: prostate-specific antigen; GG: grade group; ISUP: International Society of Urological Pathology; LUTS: lower urinary tract symptoms; MRI: magnetic resonance imaging.}

\section{Acknowledgements}

Not applicable.

Authors' contributions

SA wrote the article, made substantial contributions to conception and design of the article; TMF have been involved in drafting the manuscript and revising it critically for important intellectual content and has given the final approval of the version to be published. EJE have been involved in drafting the manuscript and revising it critically, interpretation of data and has given the final approval of the version to be published. AM, MS, EJM and FMH made critical assessment of the article and have been involved in drafting it and have given the final approval of the version to be published. All authors read and approved the final manuscript.

Funding

The authors received no specific funding for this study.

Availability of data and material

All data generated or analyzed during this study are included in this published article.

\section{Ethics approval and Consent to participate}

This study was approved by the Research Ethics Committee of the Hassan II teaching Hospital on Tuesday, February 4, 2020. All participants gave written consent prior to their operation to be included in the study.

\section{Consent for publication}

Written informed consent for publication was obtained from all participants.

\section{Competing interests}

The authors declare that they have no competing interests.

Received: 2 March 2020 Accepted: 28 December 2020

Published online: 09 January 2021 


\section{References}

1. Khoddami M, Khademi KY, Aghdam M, Soltanghoraee H (2016) Correlation between Gleason scores in needle biopsy and corresponding radical prostatectomy specimens. A twelve-year review. Iran J Pathol 11(2):120-126

2. Qarro A, Ghoundale O, Bazine K, Asseban M, Najoui M, Samir J, Ouhbi Y, Beddouch A, Lezrek M, Alami M (2012) Score de Gleason des biopsies prostatiques et celui des pièces de prostatectomies: Quelle corrélation? Afr J Urol 18(183):188

3. Boccon-Gibod LM, Dumonceau O, Toublanc M, Ravery V, Boccon-Gibod LA (2005) Micro focal prostate cancer: a comparison of biopsy and radical prostatectomy specimen features. Eur Urol 48:895-899

4. Kim SC, Jeong I, Song C, Hong JH, Kim CS (2010) Biochemical recurrencefree and cancer-specific survival after radical prostatectomy at a single institution. Korean J Urol 5:836-842

5. Khiari R, Ghobel J, Dridi M, Maarouf J, Bnerais N (2011) Ghozzis. Résulats carcinilogiques et fonctionnels de 50 prostatectomies radicales consécutives. La tunisie médicale 89:703-708

6. Peko JF, Odzebe AWS, Nsonde-Mlanda J, Bambara AT, Ngolet A (2011) Cancer de la prostate: corrélation des scores de Gleason entre les biopsies et les pièces opératoires. Prog Urol 21(9):615-618
7. D'Elia C et al (2014) Upgrading and upstaging in prostate cancer: from prostate biopsy to radical prostatectomy. Mol Clin Oncol 2:1145-1149. https://doi.org/10.3892/mco.2014.370

8. Dehayni Y, Habibi H et al (2016) Capacité de la biopsie de la prostate à prédire le score réel du cancer de la prostate? Afr J Urol 22:259-263. https ://doi.org/10.1016/j.afju.2016.02.002

9. Dolatkhah S et al (2019) Discrepancies between biopsy Gleason score and radical prostatectomy specimen Gleason score: an Iranian experience. Urol Oncol 16(1):56-61

10. Awang A, Isa NM et al (2019) Gleason scores in prostate needle biopsy and prostatectomy specimens in prostatic adenocarcinoma: a correlation study. Malays J Pathol 41(3):253-257

\section{Publisher's Note}

Springer Nature remains neutral with regard to jurisdictional claims in published maps and institutional affiliations.

\section{Submit your manuscript to a SpringerOpen ${ }^{\circ}$ journal and benefit from:}

- Convenient online submission

- Rigorous peer review

- Open access: articles freely available online

- High visibility within the field

- Retaining the copyright to your article

Submit your next manuscript at $\boldsymbol{\nabla}$ springeropen.com 